\title{
Characterization of ATP Release from Cultures Enriched in Cholinergic Amacrine-like Neurons
}

\author{
Paulo F. Santos, Olga L. Caramelo, Arsélio P. Carvalho, Carlos B. Duarte \\ Center for Neuroscience of Coimbra, Department of Zoology, University of Coimbra, \\ 3004-517 Coimbra, Portugal
}

Received 4 March 1999; accepted 27 April 1999

\begin{abstract}
Adenosine triphosphate (ATP) has been proposed to play a role as a neurotransmitter in the retina, but not much attention has been given to the regulation of ATP release from retinal neurons. In this work, we investigated the release of ATP from cultures enriched in amacrine-like neurons. Depolarization of the cells with $\mathrm{KCl}$, or activation of $\alpha$-amino-3-hydroxy5-methyl-4-isoxazole-propionate (AMPA) receptors, evoked the release of ATP, as determined by the luciferin/luciferase luminescent method. The ATP release was found to be largely $\mathrm{Ca}^{2+}$ dependent and sensitive to the botulinum neurotoxin A, which indicates that the ATP released by cultured retinal neurons originated from an exocytotic pool. Nitrendipine and $\omega$-Agatoxin IVA, but not by $\omega$-Conotoxin GVIA, partially blocked the release
\end{abstract}

of ATP, indicating that in these cells, the $\mathrm{Ca}^{2+}$ influx necessary to trigger the release of ATP occurs in part through the $\mathrm{L}-$ and the $\mathrm{P} / \mathrm{Q}$ types of voltage-sensitive $\mathrm{Ca}^{2+}$ channels (VSCC), but not through N-type VSCC. The release of ATP increased in the presence of adenosine deaminase, or in the presence of 1,3-dipropyl-8cyclopentylxanthine (DPCPX), an adenosine $A_{1}$ receptor antagonist, showing that the release is tonically inhibited by the adenosine $A_{1}$ receptors. To our knowledge, this is the first report showing the release of endogenous ATP from a retinal preparation. () 1999 John Wiley \& Sons, Inc. J Neurobiol 41: 340-348, 1999

Keywords: amacrine-like cells; ATP release; adenosine; exocytosis; retina
It is now recognized that adenosine $5^{\prime}$-triphosphate (ATP), the ubiquitous energy source of the cell, also plays a role as a neurotransmitter and as a neuromodulator in the nervous system (for reviews, see Burnstock, 1996; Sperlágh and Vizi, 1996). The receptors for ATP have been found in a large number in nervous tissues (Barnard et al., 1997), and have been classified in the P2 purinoreceptors class, in contrast to the P1 purinoreceptors which are preferentially activated by adenosine (Burnstock, 1978). Based on their pharmacological properties, Burnstock and Kennedy (1985) divided the P2 purinoreceptors in two subtypes, P2X and $\mathrm{P} 2 \mathrm{Y}$, which were later shown to also possess distinct molecular structures. The $\mathrm{P} 2 \mathrm{X}$ receptors con-

Correspondence to: C. B. Duarte

Contract grant sponsor: Praxis XXI; contract grant numbers: 2/2.1/BIA/74/94, P/BIA/10181/1998

(C) 1999 John Wiley \& Sons, Inc. CCC 0022-3034/99/030340-09 stitute a large family of at least seven subtypes $\left(\mathrm{P} 2 \mathrm{X}_{1}-\mathrm{P} 2 \mathrm{X}_{7}\right)$ of ionotropic receptors, whereas the receptors belonging to the $\mathrm{P} 2 \mathrm{Y}$ family, with six subtypes $\left(\mathrm{P} 2 \mathrm{Y}_{1}-\mathrm{P} 2 \mathrm{Y}_{7}\right)$, are coupled to $\mathrm{G}$ proteins (for review, see Barnard et al., 1997).

Molecular biology and functional studies have demonstrated the presence of P2X (Valera et al., 1994; Greenwood et al., 1997; Brandle et al., 1998) and P2Y (Keirstead and Miller, 1997; Newman and Zahs, 1997; Liu and Wakakura, 1998) receptors in the retina. However, not much attention has been given to the regulation of the release of endogenous ATP by retinal neurons, in contrast to considerable knowledge accumulated concerning the events leading to extracellular accumulation of adenosine in the retina (Blazinski et al., 1991; Paes de Carvalho et al., 1990; Santos et al., 1998a). The first evidence for the role of ATP as a retinal neurotransmitter emerged from the 
observation that extracellular ATP inhibited acetylcholine (ACh) release induced by flickering light, while ACh release was enhanced by the presence of the P2X purinoreceptor selective antagonist, pyridoxalphosphate-6-azophenyl-2',4'-disulphonic acid (Neal and Cunningham, 1994).

We recently showed that $\mathrm{KCl}$ depolarization of cultures enriched in amacrine-like neurons leads to the extracellular accumulation of adenosine (Santos et al., 1998a) by a mechanism partially dependent on the activity of ectonucleotidases, and proposed that cultured retinal neurons release ATP, in addition to acetylcholine and $\gamma$-aminobutyric acid (GABA) (Santos et al., 1998a,b). In the present work, we used cultures enriched in amacrine-like neurons to study the release of ATP evoked by membrane depolarization and by activation of the glutamate receptors. The results show that cultured retinal neurons release ATP by a $\mathrm{Ca}^{2+}$-dependent mechanism, which is under tonic inhibition by adenosine through activation of the adenosine $A_{1}$ receptors.

\section{MATERIALS AND METHODS}

\section{Materials}

Fetal calf serum was purchased from Biochrom KG (Berlin, Germany) and trypsin from GIBCO (Paisley, UK). $\omega$-Conotoxin GVIA and $\omega$-Agatoxin IVA were obtained from Peninsula Laboratories Europe (Marseyside, England) and from the Peptide Institute (Osaka, Japan), respectively. Nitrendipine was a kind gift of Dr. G. Terstappen (Bayer A. G., Germany). $S$-(4-Nitrobenzyl)-6-thioinosine (NBTI), $N^{6}$-cyclopentyladenosine (CPA), and 1,3-dipropyl-8-cyclopentylxanthine (DPCPX) were from RBI (Natick, MA). The botulinum neurotoxin A was purchased from Wako Chemicals (Neuss, Germany), and the luciferin/luciferase preparation was from Analytical Luminescence Laboratory (San Diego, CA). All other reagents were from Sigma Chemical Co. (St. Louis, MO) or from Merck (Darmstadt, Germany).

\section{Preparation and Culture of Chick Retina Cells}

Primary cultures of chick retinal neurons from 8-day-old chick (White Leghorn) embryos were obtained as described previously (Duarte et al., 1992). Briefly, the retinas were dissected free from other ocular tissues and incubated for 15 min at $37^{\circ} \mathrm{C}$, in $\mathrm{Ca}^{2+}$ - and $\mathrm{Mg}^{+}$-free Hank's balanced salt solution supplemented with $0.1 \%$ trypsin. The digested tissue was centrifuged at $140 \times g$, for $1 \mathrm{~min}$, and the pellet was mechanically dissociated in basal medium of Eagle (BME), buffered with $20 \mathrm{~m} M$ HEPES and $10 \mathrm{mM} \mathrm{NaHCO}$, and supplemented with $5 \%$ heat-inactivated fetal calf serum, penicillin $(100 \mathrm{U} / \mathrm{mL})$, and streptomycin $(100 \mu \mathrm{g} / \mathrm{mL})$. Af- ter the appropriate dilution, the cells were plated at a density of $2 \times 10^{6}$ cells $/ \mathrm{cm}^{2}$ on six-well cluster plates coated with poly-D-lysine $(0.1 \mathrm{mg} / \mathrm{mL})$. The cells were then kept in culture for 5 days at $37^{\circ} \mathrm{C}$, in a humidified atmosphere of $95 \%$ air $/ 5 \% \mathrm{CO}_{2}$, before the experiments. An antibody against choline acetyltransferase stained $81.2 \pm 2.8 \%$ of the cells present in a preparation similar to the one used in the experiments (Carvalho et al., 1998; Santos et al., 1998b), indicating that the culture conditions used favor the selective survival of cholinergic neurons. Because the starburst amacrine cells are the only cells in the retina that synthesize acetylcholine (Baughman and Bader, 1977; Masland and Mills, 1979; Hayden et al., 1980; Voigt, 1986), the cultures of chick retinal neurons are constituted mainly by amacrinelike neurons.

\section{ATP Release}

The cultures of chick retinal neurons were washed three times with $\mathrm{Na}^{+}$medium (in $\mathrm{m} M$ : $132 \mathrm{NaCl}, 4 \mathrm{KCl}, 1.4$ $\mathrm{MgCl}_{2}, 1.2 \mathrm{H}_{3} \mathrm{PO}_{4}, 1 \mathrm{CaCl}_{2}, 6$ glucose, 10 HEPES-Na, $\mathrm{pH}$ 7.4), and preincubated in the same medium, supplemented with $200 \mu M \quad \alpha, \beta$-methyleneadenosine 5 '-diphosphate (AOPCP), for $15 \mathrm{~min}$ at $37^{\circ} \mathrm{C}$. The cells were further incubated in a solution with the same composition for $1 \mathrm{~min}$, and were then stimulated for $15 \mathrm{~s}$ with the indicated stimulus. After stimulation, $0.5 \mathrm{~mL}$ of the incubation medium was collected for ATP content determination. All the media used in the ATP release experiments were supplemented with the ectonucleotidase inhibitor AOPCP (Naito and Lowenstein, 1985) at $200 \mu M$, except where otherwise indicated.

For the quantification of the total intracellular ATP content, the cells were disrupted with $1 \mathrm{~mL}$ of ice-cold lysis buffer [50 $\mathrm{m} M$ Tris- $\mathrm{HCl}, 4 \mathrm{~m} M$ ethylenediaminetetraacetic acid (EDTA), pH 7.5]. The cells were then scrapped, and the content of each well was transferred to an eppendorf tube and incubated for $90 \mathrm{~s}$ at $90^{\circ} \mathrm{C}$. After centrifugation at $15,800 \times g$, the supernatant was collected for analysis of the ATP content.

The ATP content of each sample was measured by the luciferin-luciferase method. The content of a sealed vial of the enzyme preparation, consisting of a mixture of highly purified luciferase, purified bovine serum albumin, and luciferin, was dissolved in $5 \mathrm{~mL}$ of sterile water. Then, $150-\mu \mathrm{L}$ aliquots of each sample were added to $50 \mu \mathrm{L}$ of ATP assay solution, and the luminescence was measured with a Turner luminometer (Xu et al., 1991). At the end of each experiment, a calibration was performed by addition of 2 pmol ATP.

\section{Other Methods}

Results are presented as mean \pm standard error of the mean (S.E.M.) of the number of experiments indicated. Statistical significance was determined using one-way analysis of variance (ANOVA), and differences between treatments were evaluated using Dunnett's test. 


\section{RESULTS}

\section{Resting and $\mathrm{KCl}-E v o k e d$ ATP Release}

$\mathrm{KCl}$ depolarization of cultures enriched in amacrinelike neurons induced the release of endogenous ATP. The basal release of ATP, determined after $15 \mathrm{~s}$ incubation in $\mathrm{Na}^{+}$medium supplemented with 200 $\mu M$ AOPCP, an inhibitor of $5^{\prime}$-nucleotidases (Naito and Lowenstein, 1985), was $22.9 \pm 3.1 \mathrm{pmol} / 20$ $\times 10^{6}$ cells (Fig. 1). Depolarization of the cells with $50 \mathrm{mM} \mathrm{KCl}$ for $15 \mathrm{~s}$ increased significantly the extracellular ATP content up to $67.2 \pm 5.3 \mathrm{pmol} / 20 \times 10^{6}$ cells. The intracellular ATP content measured in nondepolarized cells was $12.5 \pm 0.6 \mathrm{pmol} / 20 \times 10^{6}$ cells $(n=3)$. Therefore, the extracellular ATP content under resting conditions and after $15 \mathrm{~s}$ depolarization was $0.18 \%$ and $0.54 \%$ of the total intracellular content, respectively. When the concentration of the $5^{\prime}$ ectonucleotidase inhibitor was increased to $400 \mu \mathrm{M}$, the basal and $\mathrm{KCl}$-evoked extracellular ATP contents were not significantly different from those observed when the experiments were conducted using $200 \mu \mathrm{M}$ AOPCP $\left(33.3 \pm 9.0 \mathrm{pmol} / 20 \times 10^{6}\right.$ cells and 76.4 $\pm 0.8 \mathrm{pmol} / 20 \times 10^{6}$ cells, respectively). Therefore, all subsequent experiments were performed in the presence of $200 \mu M$ AOPCP.

The extracellular accumulation of ATP measured in response to depolarization of retina cells with 50

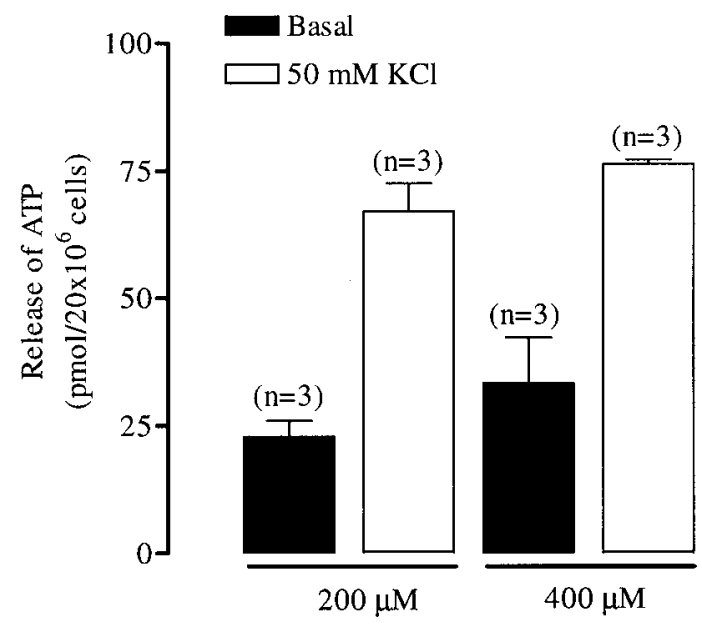

Figure 1 Effect of $\mathrm{KCl}$ depolarization on the extracellular accumulation of ATP. Cultured amacrine-like neurons were incubated for $15 \mathrm{~s}$ with $1 \mathrm{mM} \mathrm{Ca}{ }^{2+}$-containing $\mathrm{Na}^{+}$medium (Basal) or with $50 \mathrm{~m} M \mathrm{KCl}$ medium $(50 \mathrm{mM} \mathrm{KCl}$; $\mathrm{Na}^{+}$was isoosmotically replaced by $50 \mathrm{mM} \mathrm{KCl}$ ), supplemented with 200 or $400 \mu M$ AOPCP. The results are expressed as picomoles of ATP released per $20 \times 10^{6}$ cells, and are means \pm S.E.M. for the indicated number of experiments, performed in independent preparations.

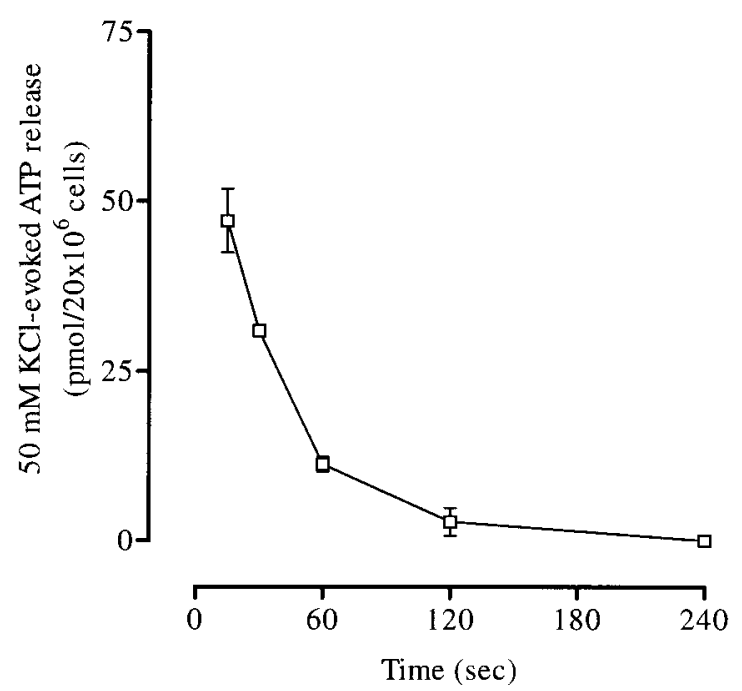

Figure 2 Time dependency of potassium-evoked extracellular accumulation of ATP from cultured chick amacrinelike neurons. The cells were stimulated with $50 \mathrm{mM} \mathrm{KCl}$ for the indicated period of time in a medium containing $1 \mathrm{~m} M$ $\mathrm{Ca}^{2+}$ and supplemented with $200 \mu M$ AOPCP. The results are expressed as pmol of released ATP above basal per 20 $\times 10^{6}$ cells, and are means \pm S.E.M. for four independent experiments, performed in independent preparations.

$\mathrm{m} M \mathrm{KCl}$ was dependent on the depolarization period (Fig. 2). Depolarization of the cells with $50 \mathrm{mM} \mathrm{KCl}$ for $15 \mathrm{~s}$, the shortest period tested, allowed the maximal extracellular accumulation of ATP, which was $47.1 \pm 4.7 \mathrm{pmol} / 20 \times 10^{6}$ cells above the basal value. When the stimulation was performed for $30 \mathrm{~s}$, the extracellular accumulation of ATP above the basal value was significantly decreased to $30.9 \pm 0.6$ $\mathrm{pmol} / 20 \times 10^{6}$ cells. This decrease of the extracellular levels of ATP was even larger for longer stimulation periods of 60 and $120 \mathrm{~s}$, where the extracellular levels of ATP were drastically reduced to $11.4 \pm 1.1$ $\mathrm{pmol} / 20 \times 10^{6}$ cells and $2.8 \pm 2.1 \mathrm{pmol} / 20 \times 10^{6}$ cells above basal values, respectively. The basal levels of extracellular ATP did not change significantly when the cells were maintained in nondepolarizing conditions for 15-240 s. Therefore, in all the experiments conducted thereafter, the cells were depolarized for $15 \mathrm{~s}$.

\section{$\mathrm{Ca}^{2+}$ Dependency of ATP Release}

Stimulation of cultured chick retinal neurons with 50 $\mathrm{m} M \mathrm{KCl}$ in $\mathrm{Ca}^{2+}$-free $\mathrm{Na}^{+}$-medium supplemented with $200 \mathrm{n} M$ EGTA increased the extracellular accumulation of ATP from $20.9 \pm 1.1$ to $34.0 \pm 3.01$ pmol ATP $/ 20 \times 10^{6}$ cells (Fig. 3 ). This effect was significantly lower than the extracellular accumula- 


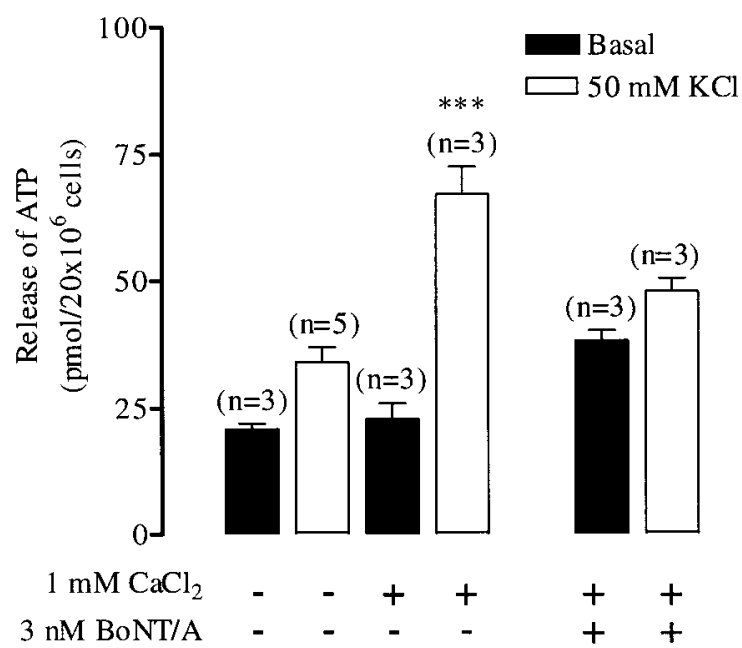

Figure 3 Effect of $\mathrm{Ca}^{2+}$ and of BoNT/A on the extracellular accumulation of ATP from cultured chick amacrinelike neurons. The cells were incubated in $\mathrm{Na}^{+}$medium (Basal) or in a medium containig $50 \mathrm{mM} \mathrm{KCl}$, for $15 \mathrm{~s}$, in the presence of $\mathrm{Ca}^{2+}\left(+\mathrm{Ca}^{2+}\right)$ or in $\mathrm{Ca}^{2+}$-free medium supplemented with $200 \mathrm{n} M$ EGTA $\left(-\mathrm{Ca}^{2+}\right)$. All experiments were conducted in the presence of $200 \mu M$ AOPCP. When the effect of the neurotoxin BoNT/A was tested, the cells were preincubated with $3 \mathrm{n} M$ BoNT/A for $24 \mathrm{~h}$ in culture medium. The results are expressed as picomoles of released ATP per $20 \times 10^{6}$ cells, and are means \pm S.E.M. for the indicated number of experiments, performed in independent preparations. $* * * p<.001$, as determined using Dunnett's test.

tion of ATP when the cells were exposed to $\mathrm{KCl}$ in the presence of $1 \mathrm{mM} \mathrm{CaCl}$ (from $22.9 \pm 3.09$ to 67.2 $\pm 5.43 \mathrm{pmol}$ of ATP/20 $\times 10^{6}$ cells).

The large $\mathrm{Ca}^{2+}$ dependency of ATP release in response to $\mathrm{KCl}$ depolarization suggests that it occurs by exocytosis. In fact, this hypothesis was supported by experiments in which we tested the effect of botulinum neurotoxin A (BoNT/A) on the extracellular accumulation of ATP evoked by $\mathrm{KCl}$. This neurotoxin cleaves SNAP-25 (Blasi et al., 1993), thereby blocking synaptic transmission. The BoNT/A $(3 \mathrm{nM})$ increased the extracellular accumulation of ATP under resting conditions, up to $38.3 \pm 2.0 \mathrm{pmol} / 20 \times 10^{6}$ cells, but the extracellular accumulation of ATP observed after depolarization was decreased to 48.0 $\pm 2.5 \mathrm{pmol} / 20 \times 10^{6}$ cells. These results show that cleavage of SNAP-25 decreases the release of ATP by about $80 \%$, clearly demonstrating that $\mathrm{KCl}$ evokes the exocytotic release of ATP from amacrine-like cell cultures.

Since the release of ATP is largely $\mathrm{Ca}^{2+}$ dependent, we studied the contribution of different types of voltage sensitive $\mathrm{Ca}^{2+}$ channels (VSCC) to the extracellular accumulation of ATP evoked by $\mathrm{KCl}$ depo- larization. Preincubation of the cells with $300 \mathrm{n} M$ nitrendipine, a blocker of the L-type $\mathrm{Ca}^{2+}$ channels (McCleskey et al., 1986; Duarte et al., 1992), did not affect significantly the release of ATP [Fig. 4(A)]. However, at $500 \mathrm{n} M$ the blocker inhibited significantly the release of ATP to $79.3 \pm 0.8 \%$ of control.

$\omega$-Agatoxin IVA ( $\omega$-Aga IVA; $1 \mu M)$, a blocker of the P/Q-type $\mathrm{Ca}^{2+}$ channels (Mintz et al., 1992; Sather et al., 1993; Zhang et al., 1993), also inhibited significantly the $\mathrm{KCl}$-evoked release of ATP, to 87.4 $\pm 7.0 \%$ of control [Fig. 4(B)]. In contrast to nitrendipine and $\omega$-Aga IVA, the neurotoxic peptide $\omega$-Conotoxin GVIA ( $\omega$-CgTx GVIA), which blocks the N-type $\mathrm{Ca}^{2+}$ channels (Olivera et al., 1985), did not affect significantly the release of ATP evoked by $50 \mathrm{~m} M \mathrm{KCl}$ at the concentrations used $(300 \mathrm{n} M$ and $500 \mathrm{n} M$ ) [Fig. 4(C)]. At $500 \mathrm{n} M$, $\omega$-CgTx GVIA inhibited maximally the release of $\left[{ }^{3} \mathrm{H}\right] \mathrm{ACh}$ and of $\left[{ }^{14} \mathrm{C}\right] \mathrm{GABA}$ from cultured retina cells (Santos et al., 1998b).

\section{Modulation of ATP Release by Endogenous Adenosine}

The activation of adenosine $A_{1}$ receptors has been shown to modulate the release of several neurotransmitters in the retina (Blazynski and Perez, 1991; Santos et al., 1998a). Since it was observed that part of the ATP released could be metabolized (Fig. 2), and since we have previously reported that depolarization of cultured retinal neurons leads to the extracellular accumulation of adenosine (Santos et al., 1998a), we investigated whether adenosine $A_{1}$ receptors could modulate the release of ATP by cultured retinal neurons. Depolarization of retina cells with $50 \mathrm{mM} \mathrm{KCl}$ in the presence of $2 \mathrm{U} / \mathrm{mL}$ adenosine deaminase (ADA), which converts extracellular adenosine into inosine (Franco et al., 1997), highly potentiated the release of ATP, to $165.3 \pm 20.2 \%$ of the control (Fig. $5)$. This potentiation was completely suppressed by $100 \mathrm{n} M N^{6}$-cyclopentyladenosine (CPA), an adenosine $\mathrm{A}_{1}$-selective receptor agonist (Palmer and Stiles, 1995) (109.2 $\pm 17.9 \%$ of control). The blockade of the adenosine $\mathrm{A}_{1}$ receptor with $100 \mathrm{n} M$ of the specific antagonist, 1,3-dipropyl-8-cyclopentylxanthine (DPCPX) (Lohse et al., 1987) also potentiated the release of ATP induced by $\mathrm{KCl}$ depolarization, up to 139.4 $\pm 4.8 \%$ of control.

\section{Effect of Glutamate Receptor Agonists on Release of ATP}

Stimulation of cultured chick retina cells with $100 \mu M$ glutamate for $15 \mathrm{~s}$ did not affect significantly the 


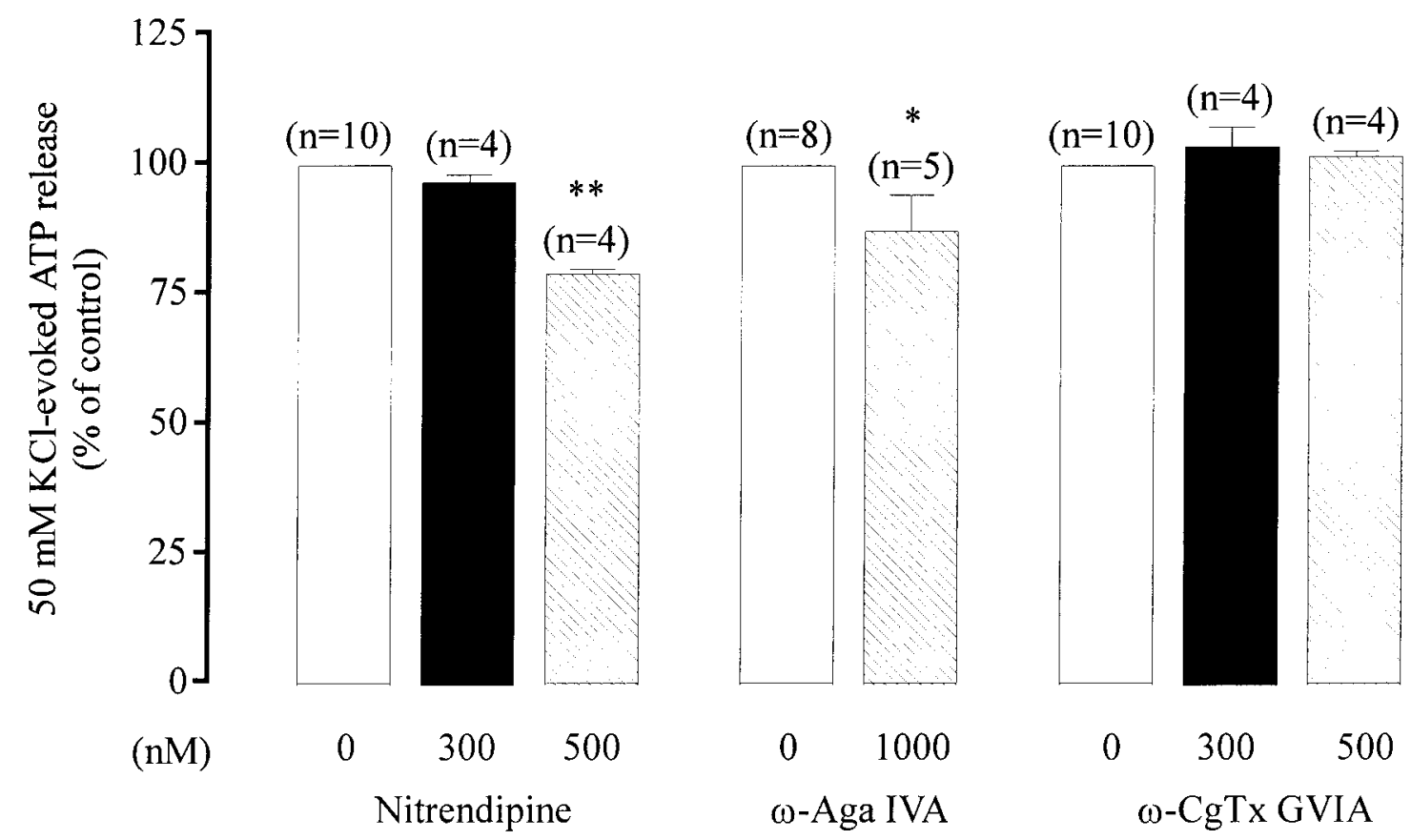

Figure 4 Effect of VSCC blockers on the $50 \mathrm{~m} M$ KCl-evoked ATP release from cultured chick

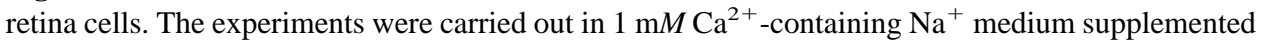
with $200 \mu M$ AOPCP. When the effect of the blockers was tested, the cells were preincubated with the indicated concentrations of nitrendipine or with $\omega$-Aga IVA for $1 \mathrm{~min}$. The incubation with $\omega$-CgTx GVIA was carried out for 45 min in culture medium. The cells were then stimulated with $\mathrm{KCl}$ for $15 \mathrm{~s}$ in the presence of the blockers, as indicated. The results are expressed as a percentage of the control, obtained after $\mathrm{KCl}$ depolarization in the absence of any blocker, and are means \pm S.E.M. for the indicated number of experiments, performed in independent preparations. ${ }^{*} p$ $<.05, * * p<.01$, as determined using Dunnett's test.

extracellular accumulation of ATP compared to the release observed in resting conditions (Fig. 6). However, stimulation with $100 \mu M$ kainate (KA) evoked the release of $37.4 \pm 1.5 \mathrm{pmol} \mathrm{ATP} / 20 \times 10^{6}$ cells. To determine whether the effect of KA was due to the activation of $\alpha$-amino-3-hydroxy-5-methyl-4-isoxazolepropionate (AMPA) receptors, we used the 2,3-benzodiazepine LY-303070, which is the active isomer of the noncompetitive AMPA receptor antagonists 1-(4aminophenyl)-3-methylcarbamyl-4-methyl-7,8-methylenedioxy-3,4-dihydro-5H-2,3-denzodiazepine (GYKI 53655) (Donevan and Rogawski, 1993; Paternain et al., 1995). At $15 \mu M$, LY 303070 inhibited the release of ATP to $28.7 \pm 2.2 \mathrm{pmol}$ ATP/20 $\times 10^{6}$ cells. Domoic acid (DO) is an agonist of the kainate receptors, which, however, may also activate AMPA receptors (Better and Mulle, 1995). Stimulation of retina cells with $1 \mu M$ DO in the presence of $15 \mu M$ LY 303070 to block completely the AMPA receptors induced the release of 31.8 $\pm 1.5 \mathrm{pmol} \mathrm{ATP} / 20 \times 10^{6}$ cells, which was not statistically different from the release observed in $\mathrm{Na}^{+}$medium.

\section{DISCUSSION}

In this study, we have shown that cultures enriched in amacrine-like neurons release ATP in response to depolarization with $\mathrm{KCl}$ or to stimulation of the AMPA receptors. The release of ATP from these cells was found to be largely $\mathrm{Ca}^{2+}$ dependent and sensitive to the neurotoxin BoNT/A, which cleaves specifically the synaptic protein SNAP-25 (Blasi et al., 1993). The sensitivity to BoNT/A indicates that the ATP released by cultured retinal neurons originated from an exocytotic pool. To our knowledge, this is the first report showing the release of endogenous ATP from a retinal preparation.

Cultured chick retina cells have been shown to possess L- (Wei et al., 1989; Duarte et al., 1992, 1996), N- (Duarte et al., 1992), and P/Q-type (Duarte et al., 1996) VSCC. In the present work, we observed that the $\mathrm{Ca}^{2+}$ influx necessary to trigger the release of ATP occurs, in part, through the L- and P/Q-types of VSCC, but not through N-type VSCC, since ATP release was blocked by nitrendipine and by $\omega$-Aga 
IVA, but not by $\omega$-CgTx GVIA. However, the small effect $(<20 \%)$ of nitrendipine and of $\omega$-Aga IVA on the release of ATP suggests the existence of a different type of calcium channel, possibly of the R type, or other $\mathrm{Ca}^{2+}$ influx pathways coupled to the release of ATP.

In a previous study, we observed that $\mathrm{KCl}$ depolarization of cultured chick retina cells leads to the extracellular accumulation of adenosine, and this effect was partially antagonized by the ectonucleotidase inhibitor AOPCP (Santos et al., 1998a). Based on this observation, we proposed that cultured chick retina cells could release ATP, which could then be hydrolyzed, thereby generating adenosine. This hypothesis was confirmed in the present work, which also shows that these cultures contain very active extracellular enzymes involved in the degradation of the ATP released. Indeed, when the cells were depolarized with $\mathrm{KCl}$, there was a significant time-dependent reduction of the extracellular accumulation of ATP, in which the highest extracellular accumulation of ATP occurred for the shortest depolarization period tested (Fig. 2). Several enzymes have been identified in the nervous system that can hydrolyze extracellularly ATP (Zimmermann, 1996). These enzymes hydrolyze the extracellular ATP very rapidly, as shown in stud-

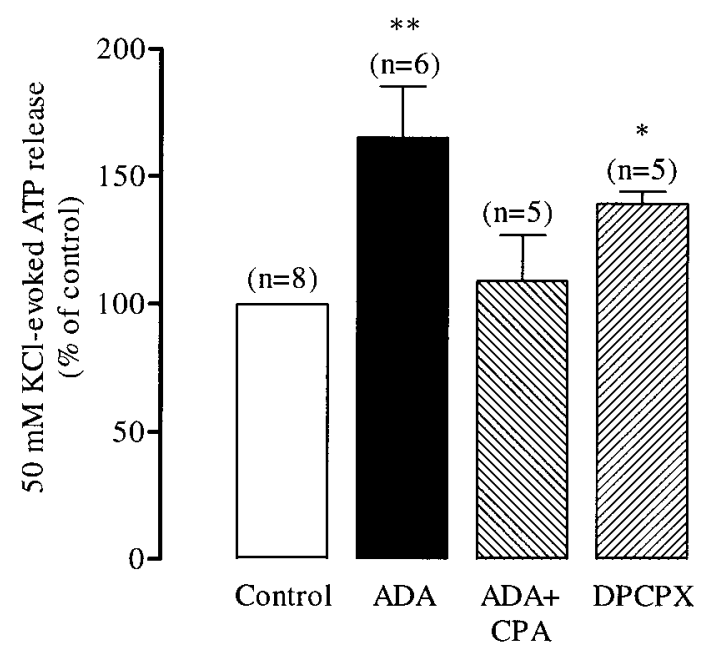

Figure 5 Adenosine $\mathrm{A}_{1}$ receptor modulation of $50 \mathrm{~m} M$ $\mathrm{KCl}$-evoked ATP release. Retina cells were incubated for 1 min with the $\mathrm{A}_{1}$ receptor agonist CPA $(100 \mathrm{n} M)$ or with the antagonist DPCPX $(50 \mathrm{n} M)$ or adenosine deaminase (ADA) ( $2 \mathrm{U} / \mathrm{ml}$ ) before and during the period of stimulation with 50 $\mathrm{m} M \mathrm{KCl}$, in $\mathrm{Na}^{+}$medium containing $1 \mathrm{~m} M \mathrm{Ca}^{2+}$ and supplemented with $200 \mu M$ AOPCP. The results are expressed as a percentage of the control, obtained after $\mathrm{KCl}$ depolarization, and are means \pm S.E.M. for the indicated number of experiments, performed in independent preparations. ${ }^{*} p<.05,{ }^{*} p<.01$ as determined using Dunnett's test.

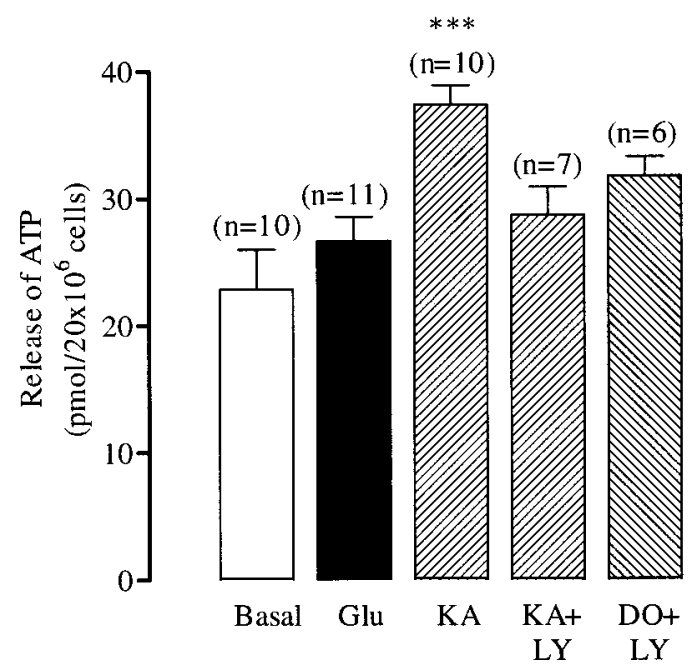

Figure 6 Effect of glutamate and glutamate receptor agonists on ATP release from cultured chick retina cells. The cells were incubated for $15 \mathrm{~s}$ with $1 \mathrm{mM} \mathrm{Ca}{ }^{2+}$-containing $\mathrm{Na}^{+}$medium (Basal) or with $\mathrm{Na}^{+}$medium supplemented with $100 \mu M$ glutamate (+Glu), $100 \mu M$ kainate (+KA), or $5 \mu M$ domoic acid (+DO). When the effect of the AMPA receptor antagonist was tested, the cells were preincubated with $15 \mu M$ LY-303070 for $1 \mathrm{~min}$. The results are expressed as picomoles of ATP released per $20 \times 10^{6}$ cells, and are means \pm S.E.M. for the indicated number of experiments, performed in independent preparations. $* * * p<.001$ as determined using Dunnett's test.

ies performed in synaptossomes from the rat striatum (James and Richarson, 1993) and from the CA1 subregion of the rat hippocampus (Cunha et al., 1998).

Adenosine triphosphate is normally considered as a cotransmitter - that is to say, it is costored with other neurotransmitters in the same synaptic vesicles (Burnstock, 1996). It was found to be costored with ACh in electron-lucent synaptic vesicles from electric fish to mammals (Volknandt and Zimmermann, 1986), as well as with noradrenaline within granules from chromaffin cells and adrenergic axons (Stjärne and Stjärne, 1995). At present, it is not clear whether vesicles exist that store ATP only and whether ATP can also be costored with other neurotransmitters, such as glutamate (Zimmerman, 1997). The localization of ATP in the retina, including cultured retinal neurons, also remains unknown. However, since adenosine is costored with ACh in displaced amacrine cells (Blazynski, 1989), and since adenosine in the retina is rapidly phosphorylated to ATP (Perez et al., 1986), it was suggested that ATP and ACh are costored in these amacrine neurons (Neal et al., 1998).

We have previously observed that the $\mathrm{Ca}^{2+}$-dependent release of $\left[{ }^{3} \mathrm{H}\right] \mathrm{ACh}$ from cultured chick amacrine-like neurons is significantly inhibited by low 
(30-nM) $\omega$-CgTx GVIA concentrations and by high (300 $\mathrm{n} M$ ) nitrendipine concentrations, and it is not affected by $\omega$-Aga IVA (Santos et al., 1998b). This effect of the VSCC blockers does not match the effects of the same blockers on the release of ATP reported here, where ATP release was found to be inhibited by $\omega$-Aga IVA but not by $\omega$-CgTx GVIA. Taken together, these results suggests that $\mathrm{ACh}$ and ATP are stored in vesicles located in different regions of the cultured amacrine cells, and are not costored in the same vesicles. This does not exclude the possibility suggested previously (Neal et al., 1994, 1998) of corelease of ATP and ACh from the same amacrine cells. However, based on our results, it is tempting to suggest that the two neurotransmitters are released from distinct pools of synaptic vesicles, one containing ACh and the other containing ATP, which may be located in different regions of the cells, endowed with different populations of VSCC.

A subpopulation of the cholinergic amacrine-like neurons used in the present studies is also GABAergic (Santos et al., 1998b). The release of $\left[{ }^{14} \mathrm{C}\right] \mathrm{GABA}$ from these cells is inhibited by low $(30 \mathrm{n} M)$ concentrations of nitrendipine, and by higher (300 to 500 $\mathrm{n} M$ ) concentrations of $\omega$-CgTx GVIA, but it is not affected by $\omega$-Aga IVA (Santos et al., 1998b). In contrast, the release of ATP from cultured retina cells could only be inhibited by higher concentrations of nitrendipine $(500 \mathrm{n} M)$, was insensitive to $\omega$-CgTx GVIA, and was slightly inhibited by the P/Q-type VSCC antagonist $\omega$-Aga IVA. These results suggest that ATP is also not costored with GABA. We cannot exclude the possibility of ATP being stored as the principal neurotransmitter in the vesicles, or being stored with other neurotransmitters besides ACh and GABA in the cultured chick retina cells.

Adenosine is known to inhibit the release of several neurotransmitters, in most cases via activation of adenosine $A_{1}$ receptors (Fredholm and Dunwiddie, 1988). This inhibition seems to extend to the neural release of ATP, since we have observed that when adenosine $A_{1}$ receptor activation was prevented by incubation with ADA, which converts adenosine into the inactive metabolite inosine, or by application of the $\mathrm{A}_{1}$ receptor antagonist $\mathrm{DPCPX}$, the release of ATP evoked by $\mathrm{KCl}$ depolarization was significantly potentiated. Conversely, when the adenosine $\mathrm{A}_{1}$ receptor was specifically activated with the agonist CPA in the presence of ADA to remove the possible effect of endogenous adenosine, the release of ATP was reduced to control levels. The modulation of ATP release by adenosine $A_{1}$ receptors was also observed in guinea-pig vas deferens, where adenosine and the adenosine $A_{1}$ receptor agonist CPA reduced the elec- trically evoked release of ATP (Kirkpatrick and Burnstock, 1992; Driessen et al., 1994). The tonic inhibition of ATP release by adenosine acting on $\mathrm{A}_{1}$ receptors resembles the effect of adenosine on the release of $\left[{ }^{3} \mathrm{H}\right] \mathrm{ACh}$ from the same cellular preparation (Santos et al., 1998a). However, this should not be taken as evidence favoring the costorage of the two neurotransmitters in the same vesicles in cholinergic amacrine cells, since the release of ATP and ACh from cholinergic retina cells is controlled by distinct VSCC (see above).

In the intact retina, glutamate is the neurotransmitter released by bipolar cells at their synapses with amacrine cells. The amacrine cells express ionotropic $N$-methyl-D-aspartate (NMDA), AMPA, and kainate receptors (Duarte et al., 1998). Although cultures enriched in amacrine-like neurons have been shown to express functional NMDA and non-NMDA ionotropic glutamate receptors (e.g., Duarte et al., 1996), glutamate was without effect on the release of ATP in this preparation. Similar results were previously reported when the effect of glutamate in the release of $\left[{ }^{3} \mathrm{H}\right]$ purines from rabbit retina was tested (Perez and Ehinger, 1989). However, kainate evoked a significant release of ATP above basal levels in cultured retina cells by activating AMPA receptors sensitive to LY 303070. Kainate was also shown to evoke the release of ATP in the rabbit retina by a mechanism independent of the activation of the kainate receptors (Perez and Ehinger, 1989). Taken together, these results suggest that activation of AMPA receptors may control the release of ATP in the retina, but it remains to be established why glutamate, in contrast to kainate, does not stimulate the release of ATP in cultured retinal neurons. It is possible that the release of ATP evoked by glutamate was not high enough to be detected. Accordingly, in previous studies using cultures enriched in amacrine-like neurons, we observed that the $\left[\mathrm{Ca}^{2+}\right]_{\mathrm{i}}$ responses evoked by kainate were higher than those caused by glutamate (Duarte et al., 1996).

Several physiological roles for ATP released by amacrine cells can be envisaged. Activation of P2X receptors by ATP was proposed to modulate ACh release through a glycinergic interneuron pathway (Neal and Cunningham, 1994). Besides being a conventional neurotransmitter in the retina, ATP may also be involved in neural-glial signaling. ATP was recently found to generate intercellular $\mathrm{Ca}^{2+}$ waves that are propagated through networks of glial cells in situ in the freshly isolated mammalian retina (Newman and Zahs, 1997). The propagation of these $\mathrm{Ca}^{2+}$ waves in retinal glial cells results in modulation of the firing rate of neighboring retinal neurons (Newman 
and Zahs, 1998). ATP may also be involved in modulating endogenous GABAergic tone by reducing the rate of uptake of GABA by the glial Müller cells (Neal et al., 1988).

The ATP released by amacrine cells may also be converted into adenosine, which activates P1 purinoceptors. These receptors are present in large amounts in the inner plexiform layer of the retina (Blazynski and Perez, 1991), where the amacrine cells are located. Activation of adenosine receptors plays an important role in the modulation of neurotransmitter release in the retina (Blazynski and Perez, 1991; Santos et al., 1998a).

In conclusion, our results show that cultured retinal neurons release ATP by a $\mathrm{Ca}^{2+}$-dependent mechanism, which is under tonic inhibition by adenosine through activation of the adenosine $\mathrm{A}_{1}$ receptors. Extracellular ATP may participate in visual processing.

This work was supported by Praxis XXI (Project Nos. 2/2.1/BIA/74/94 and P/BIA/10181/1998)

\section{REFERENCES}

Barnard EA, Simon J, Webb TE. 1997. Nucleotide receptors in the nervous system. Mol Neurobiol 15:103-129.

Baughman RW, Bader CR. 1977. Biochemical characterization and cellular localization of the cholinergic system in the chicken retina. Brain Res 138:469-485.

Bettler B, Mulle C. 1995. AMPA and kainate receptors. Neuropharmacology 34:123-139.

Blasi J, Chapman ER, Link E, Binz T, Yamasaki S, Camilli PD, Südhof TC, Niemann H, Jahn R. 1993. Botulinum neurotoxin A selectively cleaves the synaptic protein SNAP-25. Nature 365:160-163.

Blazynski C. 1989. Displaced cholinergic, GABAergic amacrine cells in the rabbit retina also contain adenosine. Vis Neurosci 3:425-431.

Blazynski C, Perez MTR. 1991. Adenosine in vertebrate retina: localization, receptor characterization, and function. Cell Mol Neurobiol 11:463-484.

Brandle U, Guenther E, Irrle C, Wheelerschilling TH. 1998. Gene expression of the P2X receptors in the rat retina. Mol Brain Res 59:269-272.

Burnstock G. 1978. A basis for distinguishing two types of purinergic receptors. In: Straub RW, Bolis L, editors. Cell membrane receptors for drugs and hormones: a multidisciplinary approach. New York: Raven Press. p107-118.

Burnstock G. 1996. Purinergic transmission. Semin Neurosci 8:171-174.

Burnstock G, Kennedy C. 1985. Is there a basis for distinguishing two types of P2 purinoreceptors? Gen Pharmacol 5:433-440.

Carvalho AL, Duarte CB, Faro CJ, Carvalho AP, Pires EV. 1998. Calcium influx through AMPA receptors and through calcium channels is regulated by protein kinase $\mathrm{C}$ in cultured retina amacrine-like cells. J Neurochem 70: 2112-2119.

Cunha RA, Sebastião AM, Ribeiro JA. 1998. Inhibition by ATP of hippocampal synaptic transmission requires localized extracellular catabolism by ecto-nucleotidases into adenosine and channeling to adenosine $\mathrm{A}_{1}$ receptors. J Neurosci 18:1987-1995.

Donevan SD, Rogawski MA. 1993. GYKI 52466, a 2,3benzodiazepine, is a highly selective, noncompetitive antagonist of AMPA/kainate receptor responses. Neuron 10:51-59.

Driessen B, von Küglegen I, Starke K. 1994. P1-Purinoceptor-mediated modulation of neural noradrenaline and ATP release in guinea-pig vas deferens. Naunyn-Schmied Arch Pharmacol 350:48-58.

Duarte CB, Ferreira IL, Santos PF, Carvalho AL, Agostinho PM, Carvalho AP. 1998. Glutamate in life and death of retinal amacrine cells. Gen Pharmacol 30:289-295.

Duarte CB, Ferreira IL, Santos PF, Oliveira CR, Carvalho AP. 1992. $\mathrm{Ca}^{2+}$-dependent release of $\left[{ }^{3} \mathrm{H}\right] \mathrm{GABA}$ in cultured chick retina cells. Brain Res 591:27-32.

Duarte CB, Santos PF, Carvalho AP. 1996. $\left[\mathrm{Ca}^{2+}\right]_{\mathrm{i}}$ regulation by glutamate receptor agonists in cultured chick retina cells. Vis Res 36:1091-1102.

Franco R, Casadó V, Ciruela F, Saura C, Mallol J, Canela EI, Lluis C. 1997. Cell surface adenosine deaminase: much more than an ectoenzyme. Prog Neurobiol 52:283294.

Fredholm BB, Dunwiddie TV. 1988. How does adenosine inhibits transmitter release? Trends Pharmacol Sci 9:130-134.

Greenwood D, Yao WP, Housley GD. 1997. Expression of the $\mathrm{P} 2 \mathrm{X}_{2}$ receptor subunit of the ATP-gated ion channel in the retina. Neuroreport 8:1083-1088.

Hayden SA, Mills JW, Masland HD. 1980. Acetylcholine synthesis by displaced amacrine cells. Science 210:435437.

James S, Richardson PS. 1993. Production of adenosine from extracellular ATP at striatal cholinergic synapse. J Neurochem 60:219-227.

Keirstead SA, Miller RF. 1997. Activation of purinoceptors on Müller cells evokes calcium release from internal stores. Soc Neurosci Abstr 498:13.

Kirkpatrick KA, Burnstock G. 1992. Evidence that the inhibition of ATP release from sympathetic nerves by adenosine is a physiological mechanism. Gen Pharmacol 23:1045-1050.

Liu Y, Wakakura M. 1998. $\mathrm{P}_{1} / \mathrm{P}_{2}$-Purinergic receptors on cultured rabbit retinal Müller cells. Jpn J Ophthalmol 42:33-40.

Lohse MJ, Klotz KN, Linbeborn-Fotinos J, Reddington M, Schwabe U, Olsson RA. 1987. 8-Cyclopenthyl-1,3-dipropylxanthine (DPCPX) a selective high affinity antagonist radioligand for $\mathrm{A}_{1}$ adenosine receptors. Naunyn-Schmied Arch Pharmacol 336:204-210.

Masland RH, Mills JW. 1979. Autoradiographic identifica- 
tion of acetylcholine in the rabbit retina. J Cell Biol 83:159-178.

McCleskey EW, Fox AP, Feldman D, Tsien RW. 1986. Different types of calcium channels. J Exp Biol 124:177190.

Mintz I, Venema V, Swiderek K, Lee T, Bean B, Adams M. 1992. P-type calcium channels blocked by the spider toxin $\omega$-Aga IVA. Nature 355:827-829.

Naito Y, Lowenstein JM. 1985. 5'-Nucleotidase from rat heart membranes: inhibition by adenine nucleotidases and related compounds. Biochem J 226:645-651.

Neal M, Cunningham J. 1994. Modulation by endogenous ATP of the light-evoked release of ACh from retinal cholinergic neurons. Br J Pharmacol 113:1085-1087.

Neal MJ, Cunningham JR, Dent Z. 1998. Modulation of extracellular GABA levels in the retina by activation of glial P2X-purinoceptors. Br J Pharmacol 124:317-322.

Newman EA, Zahs KR. 1997. Calcium waves in retinal glial cells. Science 275:844-847.

Newman EA, Zahs KR. 1998. Modulation of neuronal activity by glial cells in the retina. J Neurosci 18:40224028.

Olivera BM, Gray WR, Zeikus R, McIntosh JM, Varga J, Rivier J, Santos V, Cruz LJ. 1985. Peptide neurotoxins from fish-hunting cone snails. Science 230:1338-1343.

Paes de Carvalho R, Braas KM, Snyder SH, Adler R. 1990. Analysis of adenosine immunoreactivity, uptake, and release in purified cultures of developing chick embryo retinal neurons and photoreceptors. J Neurochem 55: 1603-1611.

Palmer TM, Stilles GL. 1995. Adenosine receptors. Neuropharmacology 34:683-694.

Paternain AV, Morales M, Lerma J. 1995. Selective antagonism of AMPA receptors unmask kainate receptor-mediated responses in hippocampal neurons. Neuron 14: 185-189.

Perez MTR, Arnér K, Ehinger B. 1988. Stimulation-evoked release of purines from the rabbit retina. Neurochem Int 13:307-318.

Perez MTR, Ehinger B. 1989. Multiple neurotransmitter system influences the release of adenosine derivates from the rabbit retina. Neurochem Int 15:411-420.

Perez MTR, Ehinger BE, Linstrom K, Fredholm BB. 1986.
Release of endogenous and radioactive purines from the rabbit retina. Brain Res 398:106-112.

Santos PF, Santos MS, Carvalho AP, Duarte CB. 1998a. Modulation of $\left[{ }^{3} \mathrm{H}\right]$ acetylcholine release from cultured amacrine-like neurons by adenosine $\mathrm{A}_{1}$ receptors. J Neurochem 71:1086-1094.

Santos PF, Carvalho AL, Carvalho AP, Duarte CB. 1998b. Differential acetylcholine and GABA release from cultured chick retina cells. Eur J Neurosci 10:2723-2730.

Sather WA, Tanabe T, Zhang JF, Mori Y, Adams M, Tsien RW. 1993. Distinctive biophysical and pharmacological properties of class $\mathrm{A}(\beta \gamma)$ calcium channel $\alpha_{1}$ subunits. Neuron 11:291-303.

Sperlágh B, Vizi SE. 1996. Neuronal synthesis, storage and release of ATP. Semin Neurosci 8:175-186.

Stjärne L, Stjärne E. 1995. Geometry, kinetics and plasticity of release and clearance of ATP and noradrenaline as sympathetic cotransmitters: roles for the nervogenic contraction. Prog Neurobiol 47:45-49.

Valera S, Hussy IV, Evans RJ, Adami N, North RA, Surprenant A, Buell G. 1994. A novel class of ligand-gated ion channel defined by $\mathrm{P}_{2 \mathrm{x}}$-receptor for extracellular ATP. Nature 371:516-519.

Voigt T. 1986. Cholinergic amacrine cells in the rat retina. J Comp Neurol 248:19-35.

Volknandt W, Zimmermann H. 1986. Acetylcholine, ATP, and proteoglycan are common to synaptic vesicles isolated from the electric organs of electric eel and electric catfish as well as from the diaphragm. J Neurochem 47:1449-1462.

Wei XY, Rutledge A, Zhong Q, Ferranti J, Triggle DJ. 1989. $\mathrm{Ca}^{2+}$ channels in chick neural retina cells characterized by 1,4-dihydropyridine antagonists and activators. Can J Physiol Pharmacol 67:506-514.

Zhang JF, Randall AD, Ellinor PT, Horne WA, Sather WA, Tanabe T, Schwartz TL, Tsien RW. 1993. Distinctive pharmacology and kinetics of cloned neuronal $\mathrm{Ca}^{2+}$ channels and their possible counterparts in mammalian CNS neurons. Neuropharmacology 32:1075-1088.

Zimmermann H. 1996. Extracellular purine metabolism. Drug Dev Res 39:337-352.

Zimmermann H. 1997. Are mechanisms of exocytosis neurotransmitter specific? Neurochem Int 31:759-761. 